\title{
Effects of partial and total substitution of fish meal with corn gluten meal on growth performance, nutrients utilization and some blood constituents of the Nile tilapia Oreochromis niloticus
}

\author{
Ataalla A. A. Metwalli \\ National Institute of Oceanography and Fisheries, Shakshouk Fish Research \\ Station, El -Fayoum, Egypt.
}

\begin{abstract}
The present study was conducted to evaluate partial or total substitution of fish meal with corn gluten meal and its effects on growth performance, nutrients utilization and blood characteristics of fingerling tilapia. Four isonitrogenous diets were formulated to contain (30.16 \pm 0.08 Crude protein) with different inclusion levels (D0, D50, D75 and D100\% corn gluten meal). Fish were fed on on the artificial diets at a rate of $3 \%$ of the fish biomass daily divided into two equal portions. Fingerlings tilapia with an initial weight of $6.65 \pm 0.2 \mathrm{~g}$ were distributed in concrete tanks as 225 juveniles in each triplicate tank of $9 \mathrm{~m}^{3}$ volume to represent 4 dietary treatments in triplicates. The experimental period lasted 105 days after start. The results showed significant differences $(\mathrm{P}<0.05)$ in growth performance and feed conversion ratio between diets. The highest performance in terms of (final weight, weight gain, average daily gain, specific growth rate, condition factor, feed conversion ratio, protein efficiency ratio, and protein productive value and Hepatosomatic index) were obtained with the $\mathrm{C} 0, \mathrm{C} 50$ and $\mathrm{C} 50 \%$, respectively, without significance difference between them. The inclusion of $100 \%$ corn gluten meal showed significant differences $(\mathrm{P}<0.05)$ with decreased growth performance and feed efficiency compared to the other tested diets. No significance difference $(\mathrm{P}<0.05)$ in whole body chemical composition (dry matter, crude protein, crude lipid and ash) was observed between fish fed on on all experimental diets. The blood parameters did not vary significantly by dietary treatments. The results of the present study indicated that, the inclusion of up to $75 \%$ corn gluten meal level as low cost plant protein instead of fish meal can be utilized in tilapia diets without adverse effects on growth performance, feed efficiency and blood characteristics.
\end{abstract}

Keywords: Oreochromis niloticus, con gluten meal, growth performance, nutrient utilization, blood characteristics.

\section{INTRODUCTION}

Aquaculture remains a growing, vibrant and important production sector for high protein food. The reported global production of food fish from aquaculture, including finfishes, crustaceans, mollusks and other aquatic animals for human consumption reached 525 million tones in 2008. The contribution of aquaculture to the total production of capture fisheries and aquaculture continued to grow rising from 34.5 percent in 2006 to 36.9 percent in 2008 (FAO, 2010). From the period from 1970 to 2008 , the production of food fish from aquaculture increased at an average of 1.6 percent per year. The combined result of development in aquaculture worldwide and the expansion in global population is that the average annual per capita supply of food fish from aquaculture for human consumption has increased by ten times, from $0.7 \mathrm{~kg}$ in 1970 to $7.8 \mathrm{~kg}$ in 2008 , at an average rate of 6.6 percent per year (FAO,2010). Production of aquaculture within region is diverse. World aquaculture is heavily 
dominated by the Asia-Pacific region, which accounts for 89 percent of production in terms of quantity and 77 percent in terms of value. Fresh waters were the source for 60 percent of the world aquaculture production in 2008 (56\% by value). Tilapia represents $7.6 \%$ of freshwater production and cultured from extensive to highly intensive systems. Tilapias species are receiving a great attention as food fish in most of Asia, Africa and Southern United State. Also, it has been successfully tested in fish culture even in dry lands harsh environments. The global aquaculture production of tilapia has drastically increased from 12.4 thousand $\mathrm{mt}$ in 1977 to 2.5 million $\mathrm{mt}$ in 2010 (FAO, 2010). The total fish production in Gulf Arabian countries were 3129912 Mt in 2009 and increased at a rate of 2.8\% yearly and the United Arab Emirates produced $77705 \mathrm{Mt}$ from the previous production. However, the fish culture in United Arab Emirates started in 1984 and became an important source for fish production, where they produced 300 tones of fish in 2003 (Khalifa bin Zayed Center for Marine Research, 2009).

The aquaculture feed industry of the world mainly depends on the use of fish meal because it is an excellent source of fundamental nutrients such as vital amino acids, essential fatty acids, vitamins, major minerals and many growth factors (Zhou et al., 2005). Rising demand, high price and unstable supply of the fish meal with the extension of aquaculture makes it compulsory to search for better alternative protein sources (Lunger et al., 2007; Lim et al., 2007; Phumee et al., 2011). Numerous studies have been undertaken to examine the effects of replacing fish meal by another sources of protein such as plant based protein diets that can be fed on to tilapia (ElEbiary, 2005; Borgeson et al., 2006; Nguyen and Davis, 2009). The plant by-products are the promising sources of protein and energy (Hardy, 2000) for the formulation of economical and environment friendly aqua feeds (Cheng and Hardy, 2002).

The primary objective for most fish farmers is to produce high quality fish at least cost. Feed typically account for $50-60 \%$ of operating costs in efficient fish farms (Tacon.1997; Essa et al., 2004). Corn gluten meal (CGM) has been successfully used as a dietary protein sources for tilapia where, the growth of $O$. niloticus fingerlings fed on corn distillers grains with soluble gluten meal as partial sources was better than that of fish fed on a 100\% fish meal in control diet (Tudor et al., 1996). Corn gluten meal was found to be a suitable protein source in a fish meal-free diet if the proper amino acid balance was maintained (Wu et al., 1995). It is highly digestible by tilapia and the digestion coefficients are comparable to fish meal protein (Koprucu and Ozdemir, 2005).

The present study aims to evaluate the potential of Corn gluten meal as plant protein source instead of fishmeal in the feeding of Nile Tilapia (Oreochromis niloticus) fingerlings and its effects on growth performance and blood characteristics.

\section{MATERIALS AND METHODS}

\section{Fish culture and experimental diets}

The present study was conducted in private fish farm at Algraain area Sharjah Emirate, United Arab Emirates. Physic-ochemical characteristics of ponds water were examined every two weeks according to APHA (1992).

Fingerlings tilapia with an average initial weight of $6.65 \pm 0.2 \mathrm{~g}$ were randomly distributed into 12 concrete ponds to represent 4 dietary treatments in triplicates and stocked at 225 juvenile per cement pond of $(3 \times 3 \times 1 \mathrm{~m})$. The experimental ponds were $9 \mathrm{~m}^{3}$ volume each. The water turnover rate is $10 \%$ day. 
Four isonitrogenous diets were formulated to contain an average of $(30.16 \pm 0.08 \%$ crude protein) in order to met the requirement of Nile tilapia (NRC, 993). The ingredients, diets formulation and chemical composition analysis are presented in Tables (1\&2). The first diet was formulated without corn gluten meal and considered as a control diet (C0). Diets 2 (C50), 3 (C75) and 4 (C100) were formulated to be comprised with partial and total inclusion levels of 50, 75 and 100\% corn gluten meal, respectively. All diets were processed into dry sinking pelleted form, using Germany pelleting machine with $2 \mathrm{~mm}$ diameter. The experimental diets were fed on at $3 \%$ rate of live body weight (BW) twice daily at 9.00 a.m and 15.00 p.m, fish samples of 30 fish were catch and weight every two weeks to adjusted feed intake. The experimental treatments were performed triplicated and lasted 105 days after start.

Table 1: Chemical composition of ingredients used in feed formulation (as\% dry matter basis).

\begin{tabular}{|l|c|c|c|c|c|c|}
\hline Ingredientes & DM & CP & EE & NFE & CF & ASH \\
\hline Fish meal & 92.8 & 70.0 & 13.5 & - & - & 16.5 \\
\hline Poultry-by-product meal & 91.0 & 56.0 & 14.8 & 12.4 & 2.2 & 14.6 \\
\hline Corn gluten meal & 92.2 & 35.0 & 2.8 & 55.4 & 2.6 & 4.2 \\
\hline Wheat bran & 91.6 & 14.0 & 3.9 & 65.8 & 9.6 & 6.7 \\
\hline Yellow corn & 89.8 & 9.0 & 2.6 & 75.8 & 8.2 & 4.4 \\
\hline
\end{tabular}

\section{Growth performance}

The following growth performance parameters were calculated as follows:

- Specific growth rate $=100 \times($ Ln final weight-Ln initial weight $) / 120$.

- Condition factor $\left(\mathrm{g} / \mathrm{cm}^{-3}\right)=($ wet weight $) /\left(\right.$ total length $\left.{ }^{-3}\right) \times 100$.

- Feed conversion $=($ feed given per fish $) /$ (weight gain per fish).

- Protein efficiency ratio $=($ weight gain per fish $) /($ protein intake per fish $)$.

- Protein productive value $(\%)=100$ (protein gain / protein fed on).

-Hepastosomatic index $($ HIS $\%)=100 \times[$ liver weight $(\mathrm{g}) /$ body weight $(\mathrm{g})]$.

Table2: Formulation and chemical composition of the experimental diets.

\begin{tabular}{|c|c|c|c|c|}
\hline \multirow[t]{2}{*}{ Ingredientes } & \multicolumn{4}{|c|}{ Diets } \\
\hline & $\mathrm{C} 0$ & $\mathrm{C} 50$ & $\mathrm{C} 75$ & $\mathrm{C} 100$ \\
\hline Fish meal & 20 & 10 & 5 & - \\
\hline Poultry-by-product meal & 20 & 20 & 22 & 22 \\
\hline Corn gluten meal & - & 20 & 30 & 40 \\
\hline Wheat bran & 10 & 37 & 32 & 31 \\
\hline Yellow corn & 43 & 6 & 4 & - \\
\hline Fish oil & 5 & 5 & 5 & 5 \\
\hline Vitamin/ Mineral Mix $^{1}$ & 2 & 2 & 2 & 2 \\
\hline Total & 100 & 100 & 100 & 100 \\
\hline \multicolumn{5}{|l|}{ Chemical composition $(\%)$} \\
\hline Dry matter & 93.5 & 93.5 & 91.8 & 92.4 \\
\hline Crude protein & 30.27 & 30.18 & 30.16 & 30.04 \\
\hline Ether extract & 15.88 & 16.14 & 16.25 & 16.44 \\
\hline Nitrogen free extract & 36.47 & 35.16 & 34.5 & 34.91 \\
\hline Fiber & 5.54 & 6.29 & 5.75 & 5.22 \\
\hline Ash & 11.84 & 12.27 & 13.34 & 13.39 \\
\hline Gross energy(MJ kg $^{-1}$ diet $)^{2}$ & 19.96 & 19.81 & 19.73 & 19.85 \\
\hline $\mathrm{ME}\left(\mathrm{MJ} \mathrm{kg}^{-1} \operatorname{diet}\right)^{3}$ & 16.74 & 16.62 & 16.57 & 16.66 \\
\hline
\end{tabular}

1-Vitamin-mineral premix supplied the following $\left(\mathrm{g} \mathrm{Kg}^{-1}\right.$ mixture); retinyl acetate 0.67 ; ascrobic acid 120; cholecolciferol 0.1 ; tocopheryl acetate 34.2 ; menodione 22 ; thiamin 5.6 ; riboflavin 12 ; pyridoxine 4.5 ; calcioum panthothenate 14.1; p-aminobenzoic acid 40; cyanocobalamin 0.03 ; niacin 30 ; biotin 0.1 ; choline chloride 350; folic acid 1.5; inositol 50; canthaxanthin 10; butylated hydroxytoluene 1.5; butylatedhydroxyanisol 1.5.; $\mathrm{CaHPO} 4,2 \mathrm{H} 2 \mathrm{O}$ 29.5; $\mathrm{Ca}$ (H2PO4)2 $\mathrm{H} 2$ O 217; NaHCO3 94.5; $\mathrm{Na} 2 \mathrm{SeO} 35 \mathrm{H} 2 \mathrm{O}$ 0.011; Kci 100; Nacl 172.4; Ki 0.2; Mgcl2 63.7; MgSO4 34.3; MnSO4 2; FeSO4H2O 10; CuSO4 5H2O 0.4; ZnSO4 10.

2-Lozano et al. (2007). 3-Jobling (1994). 


\section{Chemical analysis}

The ingredients used in feed formulation, the experimental diets and fish carcass were dried for subsequent protein (kieldahl), ether extract (Soxhlet) and moisture analysis, according to AOAC (1995) methods. Protein levels were calculated by multiplying the total nitrogen $(\mathrm{N})$ with 6.25 . Nitrogen free extract was calculated based on the difference between the dry matter content minus protein, fat and ash contents were determined according to AOAC (1995) methods.

Gross energy ( $\mathrm{MJ} \mathrm{Kg}^{-1}$ diet) was calculated according to Lozano et al.(2007) using the following calorific values: $23.9,39.8$ and $17.6 \mathrm{KJ} \mathrm{g}^{-1}$ diet for protein, ether extract and nitrogen free extract, respectively. The metabolizable energy contents of the experimental diets were calculated as $18.9,35.7$ and $14.7 \mathrm{KJ} \mathrm{g}^{-1}$ diet for protein, lipid and nitrogen free extract, respectively according to Jobling (1994).

Blood samples were collected using heparinized syringes from the caudal vein of the experimental fish at the end of the growth trial. Blood samples were centrifuged at $3000 \mathrm{rpm} \times 15 \mathrm{~min}$ at $4{ }^{\circ} \mathrm{c}$ to allow separation of plasma which use to determine the blood parameters. Total plasma protein were carried out (Colorimeteric method, Roch Diagnostics, GmbH, Monnheim, Germany) as recorded by Ruane et al., (2001). Creatinine was determined according to Pincus, (1996). The activities of aspartate aminotransferase (AST) and alanine aminotransferase (ALT) were carried out using Colorimeteric method, Roch Diagnostics, GmbH, Monnheim, Germany kits according to Reitman and Frankel (1957).

\section{Statistical analysis}

One way Analysis of Variance (ANOVA) was applied to test the effect of different dietary protein levels on various growth parameters, nutrient utilization and chemical composition of experimental fish according to Snedecore and Cochran (1987). Duncan Multiple Range test was used to detect the significant differences between the means of treatments (Duncan, 1955). All analysis was performed using SAS (version 6, 1986 SAS Institute, Cary, NC, USA).

\section{RESULTS}

\section{Physicochemical characteristics}

Water physicochemical characteristics (Table 3) revealed that temperature, $\mathrm{pH}$, dissolved oxygen, and unionized ammonia are within the optimum ranges for rearing tilapia according to (Vechklng et al., 2011). Similar physicochemical condition was observed in all ponds of the present study as presented in (Table 3 ).

Table 3: An averages of water physicochemical characteristics parameters during experimental period.

\begin{tabular}{|l|l|l|l|l|}
\hline \multirow{2}{*}{ Parameters } & \multicolumn{4}{|c|}{ Diets } \\
\cline { 2 - 5 } & \multicolumn{1}{|c|}{$\mathbf{C 0}$} & \multicolumn{1}{|c|}{$\mathbf{C 5 0}$} & \multicolumn{1}{c|}{ C75 } & \multicolumn{1}{c|}{ C100 } \\
\hline Temperature ${ }^{\mathbf{0}} \mathbf{C}$ & $27.9 \pm 1.0$ & $28.1 \pm 0.8$ & $24.2 \pm 0.32$ & $24.2 \pm 0.31$ \\
\hline Ph & $8.7 \pm 0.13$ & $8.3 \pm 0.15$ & $8.5 \pm 0.18$ & $8.6 \pm 0.12$ \\
\hline Dissolved oxygen (mg/l) & $7.5 \pm 0.14$ & $7.1 \pm 0.16$ & $7.6 \pm 0.18$ & $7.4 \pm 0.12$ \\
\hline Unionized ammonia (mg/l) & $0.032 \pm 0.01$ & $0.036 \pm 0.001$ & $0.038 \pm 0.001$ & $0.031 \pm 0.001$ \\
\hline
\end{tabular}

\section{Chemical composition of gluten meal and diets}

Results of the chemical composition of gluten meal are shown in (Table 2). results showed that the corn gluten meal contains high crude protein $(35 \% \mathrm{DM})$, high NFE (55.4\% DM), low lipid (2.8\%DM), low CF $(2.4 \% \mathrm{DM})$ and moderate ash $(4.2 \% \mathrm{DM})$. As presented in (Table 2), the experimental diets were similar in their 
protein contents ranging from (30.04 to $30.27 \%$ ) and growth energy contents ranging from (19.73 to19.96 $\mathrm{MJ} \mathrm{kg}^{-1}$ diets).

\section{Growth performance}

As presented in (Table 4), averages of initial weights ranged between 5.26 to $5.38 \mathrm{~g} /$ fish with insignificant differences among the dietary groups indicating the random distribution of the experimental fish among treatment groups. Concerning growth performance parameters (Table 4) the highest finial weights of tilapia fish $(\mathrm{P}<0.05)$ were recorded by $\mathrm{C} 0, \mathrm{C} 75$ and $\mathrm{C} 50 \%$ groups, respectively without significance difference between each other. However, C100\% corn gluten meal diet recorded lower $(\mathrm{P}<0.05)$ final weight compared to the other diets. The same trend was observed with total gain, daily gain, specific growth rate and condition factor, where $\mathrm{C} 0, \mathrm{C} 75$ and $\mathrm{C} 50 \%$ groups recorded higher values $(\mathrm{P}<0.05)$ compared to $\mathrm{C} 100 \%$ group, however differences in these traits among $\mathrm{C} 75, \mathrm{C} 0$ and $\mathrm{C} 50 \%$ were insignificant. As shown in the same table, results of survival rate were $97 \%$ for all dietary treatments groups indicating that the tested diets had no effects on tilapia fish survival rates, thus all mortalities were due to accidental factors during the samples collection every two weeks to adjust the feed amounts.

As can be seen in (Table 4), average amounts of feed consumed were found to be 235, 236, 238 and 240g for fish fed on C0,C50, C75 and C100\%, respectively, which indicate slight increases in feed consumption in fish fed on $\mathrm{C} 75$ and $\mathrm{C} 100 \%$ compared to the $\mathrm{C} 0 \%$ and $\mathrm{C} 50 \% \mathrm{CP}$. On the other hand, FCR, PER and PPV showed an insignificant differences in the values $(\mathrm{P}<0.05)$ between $\mathrm{C} 0, \mathrm{C} 50$ and $\mathrm{C} 75 \%$, respectively. In the same trend, insignificant differences were found for the hepatosomatic index (HIS) among $\mathrm{C} 75, \mathrm{C} 0$ and $\mathrm{C} 50 \%$ dietary treatments compared with $\mathrm{C} 100 \%$ group.

Table 4: Growth performance mean values of tilapia fed on the experimental diets.

\begin{tabular}{|l|c|c|c|c|}
\hline \multirow{2}{*}{ Parameters } & \multicolumn{4}{|c|}{ Diets } \\
\cline { 2 - 5 } & $\mathrm{C} 0$ & $\mathrm{C} 50$ & $\mathrm{C} 75$ & $\mathrm{C} 100$ \\
\hline Initial aveg. Weight (g/fish) & $5.38^{\mathrm{a}}$ & $5.36^{\mathrm{a}}$ & $5.26^{\mathrm{a}}$ & $5.30^{\mathrm{a}}$ \\
\hline Final aveg. Weight (g/fish) & $126.7^{\mathrm{a}}$ & $126.0^{\mathrm{a}}$ & $126.0^{\mathrm{a}}$ & $107.0^{\mathrm{b}}$ \\
\hline Total gain (g/fish) & $121.32^{\mathrm{a}}$ & $120.64^{\mathrm{a}}$ & $120.74^{\mathrm{a}}$ & $101.7^{\mathrm{b}}$ \\
\hline Average daily gain (g/fish/day) & $1.15^{\mathrm{a}}$ & $1.14^{\mathrm{a}}$ & $1.14^{\mathrm{a}}$ & $0.96^{\mathrm{b}}$ \\
\hline Specific growth rate & $3.00^{\mathrm{a}}$ & $3.00^{\mathrm{a}}$ & $3.01^{\mathrm{a}}$ & $2.86^{\mathrm{b}}$ \\
\hline Condition factor (g/cm -3 $\left.^{-}\right)$ & $1.46^{\mathrm{a}}$ & $1.42^{\mathrm{a}}$ & $1.41^{\mathrm{a}}$ & $1.25^{\mathrm{b}}$ \\
\hline Survival rate \% & 96 & 96 & 96 & 96 \\
\hline Feed consumed (g/ fish)* & 235.0 & 236.0 & 238.0 & 240.0 \\
\hline Feed conversion ratio & $1.93^{\mathrm{a}}$ & $1.95^{\mathrm{a}}$ & $1.97^{\mathrm{a}}$ & $2.35^{\mathrm{b}}$ \\
\hline Protein efficiency ratio(PER) & $1.7^{\mathrm{a}}$ & $1.69^{\mathrm{a}}$ & $1.68^{\mathrm{a}}$ & $1.41^{\mathrm{b}}$ \\
\hline Protein Productive Value (PPV\%) & $33.4^{\mathrm{a}}$ & $32.47^{\mathrm{a}}$ & $32.78^{\mathrm{a}}$ & $23.6^{\mathrm{b}}$ \\
\hline HIS (\%) & $1.43^{\mathrm{a}}$ & $1.45^{\mathrm{a}}$ & $1.46^{\mathrm{a}}$ & $1.15^{\mathrm{b}}$ \\
\hline
\end{tabular}

Means in the same row with different superscript letters are significantly different $(\mathrm{P}<0.05) . *$ Nonconsumed portion of food was collected, dried and deducted from total given ration.

\section{Blood characteristics}

Blood characteristics revealed that insignificant difference $(\mathrm{P}<0.05) \quad(\mathrm{P}<0.05)$ were detected between the experimental groups (Table,5) for total protein, albumin, creatinine, Aspartate aminotransferase (Ast) and Alanine aminotaranseferase (Alt) of tilapia, which indicate that substitution of fish meal by corn gluten meal had no hazardous effects on blood parameters tested. 
Table 5: An averages of blood characteristics parameters during experimental period as affected with inclusion levels of corn gluten meal.

\begin{tabular}{|l|l|l|l|l|}
\hline \multirow{2}{*}{ Parameters } & \multicolumn{4}{|c|}{ Diets } \\
\cline { 2 - 5 } & \multicolumn{1}{|c|}{ C0 } & \multicolumn{1}{|c|}{ C50 } & \multicolumn{1}{c|}{ C75 } & \multicolumn{1}{c|}{ C100 } \\
\hline Total protein g/dl & $6.5^{\mathrm{a}} \pm 1.11$ & $6.4^{\mathrm{a}} \pm 0.8$ & $6.42^{\mathrm{a}} \pm 0.9$ & $6.3^{\mathrm{a}} \pm 0.6$ \\
\hline Albumin g/dl & $3.28^{\mathrm{a}} \pm 0.36$ & $3.3^{\mathrm{a}} \pm 0.25$ & $3.4^{\mathrm{a}} \pm 0.35$ & $3.22^{\mathrm{a}} \pm 0.18$ \\
\hline Urea mg/dl & $7.5^{\mathrm{a}} \pm 0.14$ & $7.1^{\mathrm{a}} \pm 0.16$ & $7.6^{\mathrm{a}} \pm 0.18$ & $7.4^{\mathrm{a}} \pm 0.12$ \\
\hline Creatinine mg/dl $^{\mathbf{a}} \pm 0.16^{\mathrm{a}} \pm 0.29$ & $1.16^{\mathrm{a}} \pm 0.26$ & $1.15^{\mathrm{a}} \pm 0.16$ & $1.13^{\mathrm{a}} \pm 0.22$ \\
\hline Ast $^{\mathbf{1}}$ & $1.18^{\mathrm{a}} \pm 0.0^{\mathrm{a}} \pm 014$ \\
\hline Alt $^{\mathbf{2}}$ & $115.0^{\mathrm{a}} \pm 016$ & $118.0^{\mathrm{a}} \pm 024$ & $120.0^{\mathrm{a}} \pm 015$ & $124.0^{\mathrm{a}} \pm 015$ \\
\hline
\end{tabular}

Means in the same raw with different super script letters are significantly different $(\mathrm{P}<0.05)$.

1- Aspartate aminotransferase

2-Alanine aminotransferase

\section{Carcass analysis}

Proximate composition of whole fish body analysis did not change significantly in terms of dry matter, crude protein, crude lipid and ash contents by different dietary treatments (Table 6). However, whole fish body lipid was slightly increased by the increasing dietary corn gluten levels in the diets without significant differences $(\mathrm{P}<0.05)$ between the dietary treatments.

Table 6: Carcass analysis of tilapia fed on the experimental diets (\%w/w basis).

\begin{tabular}{|l|c|c|c|c|c|}
\hline \multirow{2}{*}{\multicolumn{1}{|c|}{ Items }} & \multicolumn{5}{|c|}{ Diets } \\
\cline { 2 - 6 } & Initial & C0 & C50 & C75 & C100 \\
\hline Dry matter & 28.5 & $28.9^{\mathrm{a}}$ & $28.8^{\mathrm{a}}$ & $28.4^{\mathrm{a}}$ & $28.8^{\mathrm{a}}$ \\
\hline Protein & 17.8 & $17.6^{\mathrm{a}}$ & $17.2^{\mathrm{a}}$ & $17.5^{\mathrm{a}}$ & $17.4^{\mathrm{a}}$ \\
\hline Lipid & 5.2 & $5.6^{\mathrm{a}}$ & $5.8^{\mathrm{a}}$ & $5.7^{\mathrm{a}}$ & $5.8^{\mathrm{a}}$ \\
\hline Ash & 5.5 & $5.7^{\mathrm{a}}$ & $5.4^{\mathrm{a}}$ & $5.2^{\mathrm{a}}$ & $5.6^{\mathrm{a}}$ \\
\hline
\end{tabular}

Means in the same raw with different super script letters are significantly different $(\mathrm{P}<0.05)$.

\section{DISCUSSION}

The proximate composition of gluten meal from protein showed that it has a good source of nutrients that could be utilized by tilapia, which indicate that it could substitute fish meal in growing tilapia diets up to $75 \%$. These results confirmed the feasibility of using gluten meal in the feed formulation of tilapia due to less cost and palatability to this species.

It was recorded by several investigations that plant ingredients contains some Anti-nutritional factors which reduce fish growth, however (Alexis, 1985 and Hardy, 2000) reported that corn gluten meal has no adverse effects on fish growth due to the lack of Anti-nutritional factors in its composition. The finding was reported in this study indicate that corn gluten meal can be used up to $75 \%$ inclusion level in tilapia diet, however, El-Ebiary, 2005 recommended 25\% corn gluten meal can used in tilapia diets. On the other side, corn gluten meal can totally replaced fish meal in catfish, Atlantic salmon and trout diets as recorded by (Lochmann et al., 2012, Burr et al., 2012 and Regost 1999) without compromising fish performance. The differences between results of the different investigators may be due to the different condition between experiments and different species.

Insignificant differences in weight gain, average weight gain, specific growth rate and condition factor of tilapia fed on the $\mathrm{C} 0, \mathrm{C} 50$ and $\mathrm{C} 75 \%$ corn gluten meal inclusion levels declared that these inclusion levels of 50 and $75 \%$ can be utilized in feeding of this species. Subhadra et al. (2006) suggested that fish growth efficacy can be affected by diet composition and feeding trial duration. Similar results for gain, 
specific growth rate and condition factor were recoded in the same species by Luo et al. (2012), Al-Asgah et al. (2011), Borgeson et al. (2006), Soltan et al. (2008) and in catfish by Lochman et al. (2012). The present study reveal that feed conversion ratio was significantly affected by corn gluten inclusion levels, thus tilapia fed on C0,C50 and $\mathrm{C} 75 \%$ corn gluten meal gave the best $(\mathrm{P}<0.05)$ feed conversion ratios compared with $\mathrm{C} 100 \%$ diet. Comparable feed conversion ratio was reported in tilapia by Koprucu and Ozdemir (2005), Wu et al. (2000) and Al-Asgah et al. (2011). On the other hand, the utilization values of protein show that it was well utilized by fish fed on different inclusion levels, where PER and PPV\% achieved the highest values for the $\mathrm{C} 0, \mathrm{C} 50$ and $\mathrm{C} 75 \%$ and then reduced in $\mathrm{C} 100 \%$. Similar results were recorded in tilapia by Luo et al. (2012) and Yones and Abdel-Hakiem, (2010) and other species such as carp Jahanbakhi et al. (2012) and trout, Burr et al. (2012). The HIS is often used as an indicator of condition and nutritional status of fish. The HSI values of the present study was similar to the values recorded for tilapia (Yones and Abdel-Hakim, 2010).

The blood parameters of tilapia were not affected by dietary inclusion levels. These results are in agreement with those recorded in tilapia by Shalaby (2004) and turbot Nagle et al. (2012).

With regard to the whole body composition of Nile tilapia fed on the several treatments, there were no indications that the increase inclusion of corn gluten meal affected the proximate composition of dry matter, crude protein, crude lipid and ash. The present results are in agreements with the results of El-Ebiary (2005) Lin et al. (2007) and Al-Asgah et al. (2011) in the same species and Tusche et al.(2012) in trout and Jahanbakhi et al. (2012) in carp.

In conclusion, the present trial confirms that corn gluten meal can be incorporated up to $75 \%$ in typical practical diets of tilapia without affecting growth performance, nutrients utilization and blood characteristics. This study also declared the feasibility of using corn gluten meal in the fish feed formulations as alternative and cheaper protein source compared to fish meal especially in tilapia fish diets.

\section{REFERENCES}

AOAC (1995). Association of Official Analytical Chemists 14ed. Assoc Office, Anal. Chem, Washington, Dc.

APHA (1992). Standard methods for the examination of water and waste water. American Public Health Association, Washington, DC, 1134pp.

Al-Asgah, N. A; Younis, E. M.; Abdel-Warth, A.A.; El-Khaldy.A.A. and Ali, A. (2011). Effect of feeding olive wast on growth performance and muscle composition of Nile tilapia (Oreochromis niloticus). Int. J. Agric. Biol., 13:239244.

Alexis, M. N.; Paparaskeva-Papoutsoglou and Theochri,V. (1985). Formulation of practical diets for rainbow trout (Salmo gairdneri) made by partial or complete substitutes for fish meal by poultry by-product and certain plant by-product. Aquaculture,50:61-73.

Borgeson, T.L.; Racz, V.J.; Wikie, D.C.; White, L.J. and Drew, M.D. (2006). Effect of replacing fish meal and oil with simple or complex mixture of vegetable ingredients in diets fed on to Nile tilapia Oreochromis niloticus. Aquaculture Nutr. 12: 141-149.

Burr, G.S.; Wolters, W.R.; Barrows, F.T. and Hardy, R.W. (2012). Replacing fish meal with blends of alternative proteins on growth performance of rainbow trout 
(Oncorhynchus mykiss) and early or late stage juvenile Atlantic salmon (Salmo salar). Aquaculture, 334: 110-116.

Cheng, Z. J. and Hardy, R.W. (2002). Effect of microbial phytase on apparent nutrient digestibility of barley, canola meal, wheat and wheat middings, measured in vivo using rainbow trout (Oncorhynchynchus mykiss). Aquaculture Nutr., 8: 271-277.

Duncan, D.B. (1955). Multiple ranges and multiple F. test. Biometric, 11, 1-42.

El-Ebiary, E. H. (2005). Use of soybean meal and/or corn gluten meal as partial substitutes for fish meal in Nile tilapia (Oreochromis niloticus) fingerlings diets. Egyption Journal of Aquatic Research, 31(2): 432-442.

Essa, A. M.; Nour, A. M.; Mabrouk, H. A. and Zaki, M. A. (2004). Rearing environmental friendly freshwater fish in floating cages. The second workshop on Fish culture Development Beehera Governorate. Oct., 11, Fac. Agric. Damanhour. Branch, Alex. Univ. Damanhour, branch, alex. Univ., Damanhour Egypt.

FAO. (2010). FAO Fisheries Department. Fishery Information. Data and Statistics Units. DISHSTAT Plus: Universal software for fishery statistical time series, Version, 23. 2000. Data sets:Aquaculture production: quantities and values 19502009, capture production 1950-2009.

Hardy, R.W. (2000). New devolopments in aquatic feed ingredients and potential of enzyme supplements. In Cruz-Sarez,L.E., Requatic-marie.D., Tapian, Salazar, M.Olvera-Novoa, M.A., Clivera-Cereoedo, R. (Eds). Avances on Nutricieion, Acuicola,V. Memorias del V. Aimposium Internacional de Nutricion Acuicala, Yucatan, Mexico, pp.216-226.

Jahanbakhi, A., Ramazi, F.G.and Soudagar, M. (2012). Effed onct of dietary corn gluten meal supplementation on body composition and growth performance in common carp (Cyprinus capio) juvenile. Golobal Veternaria, 9 (1) : 85-88.

Jobling, M. (1994). Fish bioenergetics, Series, 13 published by Chapman \& Hall-2-6 Boundary, R, London SBI 8HN, 300pp.

Khalfa bin Zayed Center for marine research (2009). Report for fish production in United Arab of Emarats.

Koprucu, K. and Ozdemir, C. (2005). Apparent digestibility of selected feed ingredients for Nile tilapia (Oreochromis niloticus). Aquaculture, 250:308-316.

Lim, C.; Garcia, J.C.; Yildirum-Akosoy, M.; Klesius, P. H.; Shoemaker,C. A. and Evans, J.J. (2007). Growth response and resistance to Streptocccs iniae of Nile tilapia Oreochromis niloticus fed ondiets containing distillers grains with solubles. J. World Aquacilt.Soc.,38:231-237.

Lin, S. M.; Mai, K. S. and Tan, B. P.(2007). Compound on growth body composition and immunity of tilapia (Oreochromis niloticus $\times$ O.aureus). Oceanologia et Limnologia Sinca, 38:168-172.

Lochmann, R.; Engle,C.; Kumar, G.; Li, M.H.; Avery, J. L.; Bosworth, B. G. and Tucker, C. S.(2012). Multi- batch catfish production and economic analysis using alternative (low cost) diets with corn gluten feed and traditional diets with meat and bone meal. Aquaculture, 366:34-39.

Lozano, N.B.S.; Vidal, A.T.; Martinez-Llorens, S.; Merida, S.N.; Blanco,J.E.; Lobez, A.M.; Torres, M.P. and Cerda, M.J. (2007). Growth and economic profit of gilthead sea bream (Sparus aurata L.) fed on sunflower meal. Aquaculture, 272: 528-534.

Luo,Z.; Tan, X.Y.; Liu,C.X.; Li, X.D.; Liu, x.J. and Xi, W.Q. (2012). Effect of dietary conjugated linoleic acid levels on growth performance, muscle fatty acid profile, hepatic intermediary metabolism and antioxidant responses in genetically 
improved farmed tilapia strain of Nile tilapia Orechromis niloticus. Aquaculture Research, 43: 1392-1403.

Lunger, A. N.; Mclem, E. and Craig, E. (2007). The effect of organic protein supplementation upon growth, feed conversion and texture quality parameters in juvenile cobia (Rachycontron canadun). Aquaculture, 264: 342-352.

Nagle, F.; Danwitz, A.; Tusche, K.; Kroeckal, S.; Bussel, C.G.; Schlachter, M.; Adem, H.; Tressel, R. and Schulz, C. (2012). Nutritional evaluation of rapeseed protein isolate as fish meal substitute for juvenile turbot (Psetta maxima L.). impact on growth performance, body composition, nutrient digestibility and blood physiology. Aquaculture, 356:357-364.

Nutional Research Council (1993). Nutritional Requirements of Fish. Nutional Research Council. National Academy Press. Washington. DC. USA.

Nguyen, T. and Davis, D. A. (2009). Evalution of alternative protein sources to replace fish meal in practical diets for Juvenile tilapia Oreochromis spp. J. World Aquaculture Soc., 40, 113-121.

Phumee, P.; Wei, W.Y.; Ramachandran, S. and Hashim, R. (2011). Evaluation of soybean meal in the formulated diets for juvenile Pungusiandon hypophthalms (Sauvage, 1878). Aquaculture Nutrition, 17:511-517.

Pincus, M. R. (1996). Interpreting laboratory results reference values and decision making. In: Henry, J. B. (Ed), Clinical Diagnosis and Management by laboratory Methods. Saunders, Philadelphia, USA, pp. 79-91.

Reitman, A. and Franks, S. (1957). Determination of aspartate glutamic amino transferadse and alanin aminotransferase. Am.J. Clin.Path., 28-56.

Regost,C.; Azel, J. and Kausshik, S. J. (1999). Partial or total replacement of fish meal by corn gluten meal in physiological and biochemical parameters in rainbow trout (Oncorhynchus mykiss). Aquaculture Nutrition, 14: 110-119.

Ruane, N.M.; Huisman, E.A. and Comen, J. (2001). Plasma cortisol and metabolite level profiles in two isogenic strains of common carp during confinenat. J.Fish Biol., 59:1-12.

SAS (1986). SAS User's Guide Version 6 Edition. SAS Institute,Cary,NC.USA.

Shalaby, S. (2004). Response of Nile tilapia Oreochoromis niloticus fingerlings to diets supplemented with different levels of fenugreek seeds (Hulba). J. Agric. Sc. Mansoura Univ., 29 (5): 2231-2242.

Snedecore, W.G. and Cochran, W.C.(1987). Statistical Methods. Iowa state Univ., USA.

Subhadra, B.; Lochmann, R.; Rawles, S. and Chen, R. (2006). Effect of dietary lipid source on growth, tissue composition and hematological parameters of largemouth bass (Micropterus salmoides). Aquaculture, 255:210-222.

Soltan, M.A.; Hanefy, M. A. and Wafa, M.I.A. (2008). Effect of replacing fish mealby a mixture of different plant protein sources in Nile tilapia (Oreochromios niloticus L.) diets. Glob. Vet.,2: 157-164.

Tacon, A. G. (1997). Fish meal replaceries: review of antinutrients within oilseeds and pulses- a limiting factor for the aquafeed Green Revolution In:Tacon, A. G., Basurco, B. (Eds), Feeding Tomorrow's Fish-Proceedings of the workshop of the GHEAM Networkon Technology of Aquaculture in the Mediterranean (TECAM), Zaragoza, Spain , pp.153-182.

Tudor, K.W.; Rosali, R.R.; Rourke, P.D.O.; Wu,Y.V.; Sessa, D. and Brown,P. (1996). Technical and economic feasability of farm fish production using fish meal analogs. Aquaculture, Eng., 15:53-65. 
Tusche, K.; Arning, S.; Wuertz, S.; Susenbeth, A. and Schulz, C. (2012). Wheat glutein and potato protein concentrate- promising protein sources for organic farming of rainbow trout (Oncorhynchus mykiss). Aquacultur, 344:120-125.

Vechklang, K.; Boonmuntanasarn; Ponchunchoovong, S.; Pirarat, N. and Wanapu,C. (2011). The potential for rice win residual as an alternative protein source in a practical diet for Nile tilapia (Oreochromis nilotics) at the juvenile stage. Aquaculture Nutr., 17:685-694.

Wu, Y.V.; Rosali, R. R.; Sessa, D. and Brown, P. (1995). Utilization of corn gluten feed by Nile tilapia. Prog. Fish Cult., 57:305-309.

Wu, Y.V.; Rosati, R.; Warner, K. and Brown, P. (2000). Growth, feed conversion, protein utilization and sensory evaluation of Nile tilapia feed diets containing corn glutein meal, ful-fat soyabean and synthetic amino acid. Journal of Aquatic Food Product technology, 9(1):77-87

Yones, A. and Abdel-Hakim. N. F. (2010). Studies on growth performance and apparent digestibility coeffficient on some common plant protein ingreidents used in formulated diets of Nile tilapia (Oreochromis niloticus). Egyption J.Nutrition and Feeds, 13:589-606.

Zhou, Q.C.; Mai, K. S.;Tan, B. P. and Liu, Y.J. (2005). Partial replacement of fish meal by soybean meal in diets for juvenile cobia (Rachycentron canodum). Aquaculture Nutrition, 11: 175-182.

\section{ARABIC SUMMARY}

$$
\begin{aligned}
& \text { الإحلال الجزئي و الكلى لمسحوق الأسماك بمسحوق جلوتين الذرة في العلائق التطبيقية لاصبعيات البلطي } \\
& \text { النيلى وتأثيرة على أداء النمو ، الكفاءة الغذائية و خون العواص الدام. } \\
& \text { عطاللة عبد التواب أحمد متولي }
\end{aligned}
$$

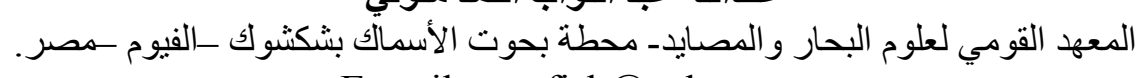

$$
\begin{aligned}
& \text { E-mail: ata_fish@yaho.com }
\end{aligned}
$$

أجريث الدراسة لتقييم تأثير الإحلال الجزئي و الكلى لمسحوق جلوتين الذرة محل مسحوق الأسماك وتأثير

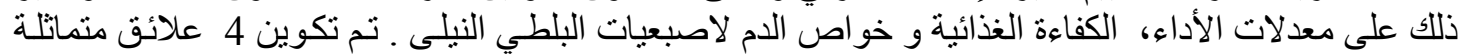

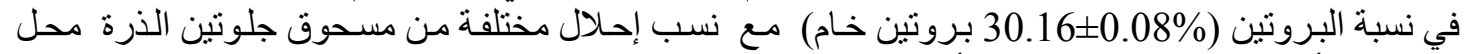

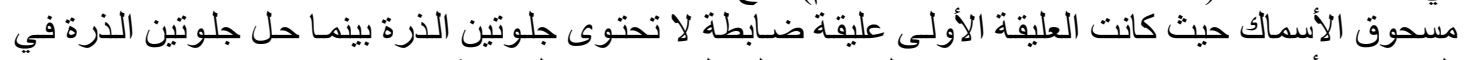

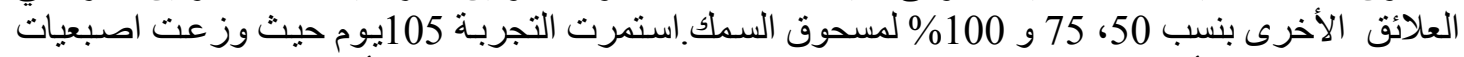

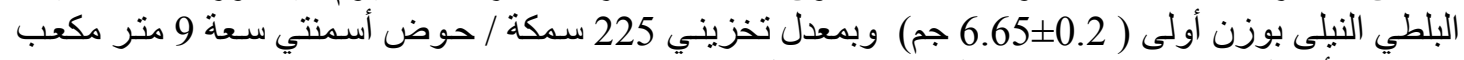

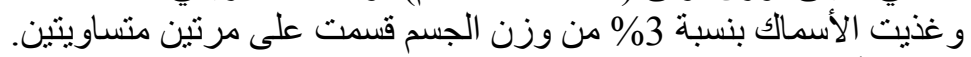

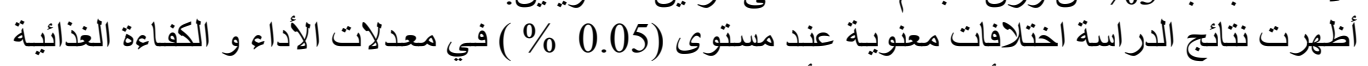

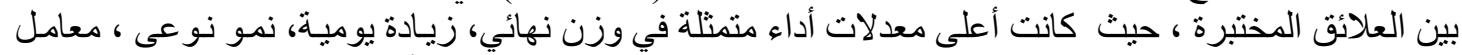


\% ع0,C50,C75\%

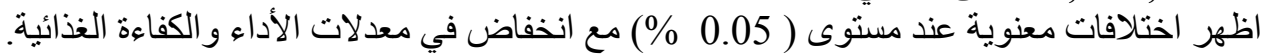

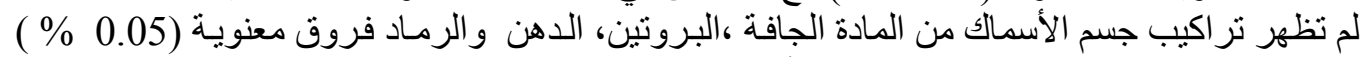

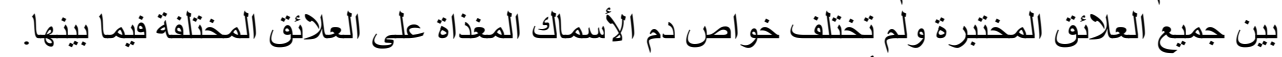

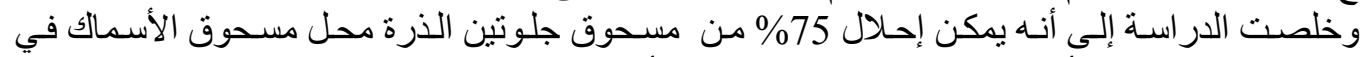

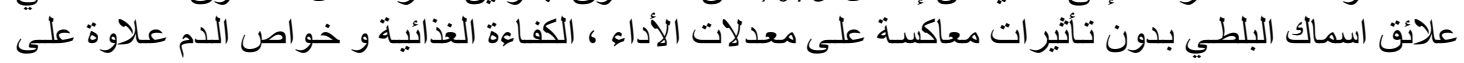
استخدام مصدر بروتين نباتي بديل لتقليل نسبة استخدام مسحوق التيل معدل السمك مرتفع الثمن. 